\title{
ORIS RAZISKOVANJA NA PODROČJU OKOLJSKE GEOGRAFIJE OB 90-LETNICI ODDELKA ZA GEOGRAFIJO LJUBLJANSKE FILOZOFSKE FAKULTETE
}

dr. Dušan Plut

Oddelek za geografijo, Filozofska fakulteta Univerze v Ljubljani

Aškerčeva 2, SI- I000 Ljubljana

e-mail: dusan_plut@t-2.net

Pregledni znanstveni članek

COBISS 1.02

\section{Izvleček}

Teoretične geografske smernice na področju okoljske geografije v Sloveniji sta po 1970 zasnovala S. Ilešič in D. Radinja. Sodelavci Oddelka so izdelali številne raziskave o antropogeni preobrazbi Slovenije in njenih pokrajin. Kasneje se je raziskovalno polje okoljske geografije razširilo delno tudi v smeri geografske prognoze. V prihodnje naj bi se okoljsko raziskovalno delo usmerilo na področji ekološke geografije in geografije sonaravnega razvoja.

Ključne besede: okoljska geografija, onesnaženost okolja, varstvo geografskega okolja, ekološka geografija, geografija sonaravnega razvoja, Slovenija

\section{AN OUTLINE OF INVESTIGATION IN THE FIELD OF ENVIRONMENTAL GEOGRAPHY ON THE OCCASION OF THE 90 th ANNIVERSARY OF THE DEPARTMENT OF GEOGRAPHY AT THE FACULTY OF ARTS IN LJUBLJANA}

\footnotetext{
Abstract

Theoretical geographical guidelines of environmental geography in Slovenia were schemed in the first half of the 1970s by S. Ilešič and D. Radinja. The associates of the Department conducted numerous investigations into the anthropogenic transformation of Slovenia, and its landscapes.
}

Key words: environmental geography, pollution, protection of geographical environment, ecological geography, sustainable development geography, Slovenia 


\section{UVOD}

V zgodovini geografije sta bila po mnenju Herberta in Matthewsa (2004) okolje in geografski prostor ključni vsebinski polji povezovanja različnih geografskih pristopov in geografskih vsebin. Ilešič (1973) je poudaril, da je razmerje med okoljem in naravo za geografijo eden osrednjih problemov že vse od 19. st. dalje. Naraščajoče negativne okoljske razsežnosti gospodarskega in tehnološkega razvoja so spodbudile integracijo raziskovanj družbe in okolja, okoljska geografija torej predstavlja ponovno aktualen in prenovljen skupni predmetni dežnik geografskega raziskovanja preobrazbe in varovanja okolja, narave, ki s sicer različnimi inačicami sodobnega geografskega environmentalizma utrjuje pomen geografije kot mavrične in 'mostiščne', a enotne znanosti. Okoljska geografija torej poudarja soodvisnost med spremembami okolja in družbe ter opozarja na velike, pa vendar omejene zmogljivosti okolja, narave, za zadovoljevanje vse večjih materialnih potreb naraščajočega svetovnega prebivalstva. Upravičeno je pričakovanje, da bo okoljska geografija uspela uravnotežiti raziskovanje geografskih diagnoz in geografskih prognoz slovenskih pokrajin in pokrajinotvornih sestavin, ki so $\mathrm{v}$ različnih fazah antropogene preobrazbe.

\section{ORIS KORENIN RAZVOJA RAZISKOVANJA NA PODROČJU OKOLJSKE GEOGRAFIJE ODDELKA ZA GEOGRAFIJO LJUBLJANSKE FILOZOFSKE FAKULTETE}

Bohinec (1938) je sicer že pred drugo svetovno vojno napisal članek o različnih načinih varstva narave na Poljskem, podprl znanstveni način preučevanja narave in potrebo po naravovarstvenem ozaveščanju. Strokovno poglobljeno zanimanje in raziskovanje problematike varstva okolja in narave pa se je v Sloveniji začelo s prizadevanji za ustanovitev Triglavskega narodnega parka že po prvi svetovni vojni. V obdobju takoj po drugi svetovni vojni je bilo tudi v slovenski geografiji v ospredju poudarjanje pozitivnih prebivalstvenih in ekonomskih posledic pospešene industrializacije in urbanizacije. Vendar so se v 60. in 70. letih 20. st. pojavila in okrepila vse bolj jasna geografska in druga opozorila (takrat politično nezaželena) o tudi vse bolj številnih negativnih okoljskih posledicah pospešenega gospodarskega razvoja.

Za kasnejšo osnovno usmeritev znanstvenoraziskovalnega in izobraževalnega delovanja na okoljskem vsebinskem polju Oddelka za geografijo ljubljanske Filozofske fakultete (v nadaljevanju Oddelka) je izjemno pomembno stališče Ilešiča (1959) o pomenu obravnave geografskega okolja kot celote, ki jo je takrat vplivna sovjetska dualistična geografija večinoma obravnavala kot nemarksistično. Ilešič (1959) je dosledno in argumentirano zagovarjal stališče, da naj bi geografsko okolje preučevala (enotna) geografija kot celoto, njegove posamezne elemente pa posamezne veje geografije. Vztrajno je zastopal stališče, da ravno geografija lahko postane most med prirodnimi in družbenimi vedami, kar posledično pomeni, da je potrebno pri okoljevarstveni in naravovarstveni problematiki upoštevati pomen in medsebojno povezanost, součinkovanje fizičnogeografskih in tudi družbenogeografskih dejavnikov, vključno s preostanki preteklosti v pokrajini kot antropogenih elementih 'resničnega geografskega okolja' (Ilešič 1962; 1964). 
V 60. letih. 20. st. je bila sicer osnovna pozornost namenjena konkretni problematiki varstva narave, zlasti nasprotovanju načrtovani gradnji hidroelektrarn v Zgornjem Posočju, zaščiti narave krasa, problematiki onesnaženosti Blejskega jezera in morja ter propadanju gozda zaradi onesnaženosti zraka. Slovenska geografija, vključno s takratnimi sodelavci Oddelka, se je (skupaj zlasti z nekaterimi naravoslovnimi vedami) posamično odzvala na vse bolj perečo problematiko onesnaževanja okolja in varovanja narave. Tako sta se na občutljivo problematiko varovanja narave krasa Slovenije in zgornje doline Soče v 60. letih 20. st. med geografi (ob P. Kunaverju, F. Habetu in P. Habiču) z zahtevo po večplastnem, tudi naravovarstvenem in pejsažnem (pokrajinskem) ovrednotenju kritično odzvala tudi Radinja (1965; 1966) in Gams (1968; 1969).

V letu 1967 je Radinja (1967) z geografskega zornega kota celovito ovrednotil načrte o zaščiti kraške pokrajine na Tržaškem. Ob argumentirani podpori načrtom zaščite krasa je med drugim zapisal (Radinja 1967, 119-120): »Iz razstavnega gradiva je tudi razvidno, da je sedaj v ospredju predvsem težnja po zavarovanju Tržaškega Krasa zaradi njegovih prirodnih posebnostih, bolj kot potreba po aktivnem in načrtnem urejanju pokrajine kot celote«, in zaključil: »Kakor pozdravljamo, da se naglaša vrednost in pomen tržaške kraške pokrajine ter da se porajajo zamisli in načrti o varovanju njenih prirodnih in kulturnih vrednot in celo pobude o smotrnem in kompleksnem načrtovanju njenega razvoja, tako imamo pomisleke, kadar se pri tem pozablja na človeka, v tem primeru slovenskega, ki na tej zemlji živi in je v njej doslej tudi ohranjal vse tiste poglavitne poteze, ki so danes predmet občudovanja, pa hkrati tudi teženj po njihovem očuvanju. Upravičeno lahko pričakujemo, da bi pri nadaljnjem razvoju teh načrtov bolj upoštevali tudi to stran celotne problematike« (Radinja 1967, 120-121).

$\mathrm{V}$ navedenih stavkih je na konkretnem primeru dejansko zarisana želena in ključna metodološka in vsebinska usmeritev nastajajoče geografije degradacije in varstva okolja na Oddelku in posledično celotne kasnejše slovenske 'okoljske' geografije:

- nujnost upoštevanja medsebojno povezanega in soodvisnega razmerja med okoljem, naravo na eni in aktivnim delovanjem človeka, družbe na drugi strani;

- razvojno-varovalna obravnava kulturne pokrajine in geografskega okolja;

- regionalnogeografsko kompleksno preučevanje in načrtovanje razvoja območij varovanja in degradacije okolja, ki pa ne sme prezreti svojstvenih geografskih značilnosti pokrajin in vloge prebivalcev;

- prednostno povezovanje posameznih spoznanj geografskih vej na okoljskem polju.

V 70. letih 20. st. so razvoj okoljske geografije na Oddelku in izven njega najprej uvodoma dodobra ključno in dolgoročno zaznamovale poglobljene teoretično-metodološke razprave o predmetu in vsebini geografskega preučevanja okolja, njegovega onesnaževanja (širše degradacije) in varovanja. V začetku 70. letih 20. st. sta ob A. Lahu (1972) predvsem Ilešič $(1972 ; 1973 ; 1979)$ in Radinja $(1972 ; 1974)$ teoretično, metodološko in terminološko zasnovala potrebne okvirje ne le za geografsko opredelitev razmerja človek - okolje, temveč tudi za (pre)potrebne geografske raziskave o vse bolj perečih okoljskih problemih v slovenskih pokrajinah. Zlasti z metodološkega vidika pa je po mnenju pisca neupravičeno ostal v ozadju tehten prispevek Orožna Adamiča (1970), ki je s pomočjo niza 41 faktorjev izdelal za takratne slovenske raziskovalne razmere inovativno kompleksno ovrednotenje estetike 
pokrajine na primeru Soče (glede na naravovarstveno in pokrajinsko škodljiv projekt načrtovane gradnje hidroelektrarne Kobarid).

Skupna 'zelena' geografska nit teroretično-metodoloških prispevkov obravnavanega prelomnega obdobja je zavzemanje za enotno pojmovanje geografskega okolja, obravnava onesnaženosti (degradiranosti) geografskega okolja (zgolj) kot določene stopnje preobrazbe okolja, pokrajine. Ilešič (1972) je upravičeno opozoril, da zaradi geografske tradicije preučevanja problemov odnosa med okoljem in človekom dejansko ni težko opredeliti kompleksnega interesa in aspekta geografije za sodobna vprašanja človekovega okolja. Geografski vidik obravnavanja okolja pa mora po njegovem mnenju seči daleč čez ožji aspekt zaščite narave ter zajeti vso problematiko prostora, njegovega urejanja in preurejanja (Ilešič 1972, 5). Povedano drugače - geografija naj razen kompleksne geografske diagnoze večjo pozornost nameni tudi načrtovanju, torej geografski prognozi.

Z vidika neposrednega vpliva na vsebino prihodnjih konkretnih geografskih raziskav okolja pa je posebej pomembna ugotovitev Radinje (1972), da onesnaženost okolja ni zgolj posledica človekovega razvoja, temveč tudi faktor tega razvoja. Obenem, po njegovem prepričanju, prav preučevanje onesnaženosti okolja potrjuje smisel geografije kot kompleksne vede, saj je geografija kratkomalo veda o okolju (Radinja 1974, 111). Prav tako je pomembna njegova daljnovidna sporočilna nota (Radinja 1972, 37), »da destruktivno spreminjanje okolja temelji tudi na prepričanju, da so bistvene sestavine prirodnega okolja praktično neizčrpne. Teh snovi doslej res ni zmanjkalo, primanjkuje pa že sedaj dobrega zraka, dobre vode in dobrih tal, ker je presežena regeneracijska zmogljivost geosfere in posameznih njenih pokrajin«. Radinja (1972) je torej pred pojavom sprememb podnebja na globalni ravni opozoril na preseganje regeneracijskih zmogljivosti planeta, na medsebojno povezanost lokalnega, regionalnega in globalnega geografskega okolja. Gams (1972) pa je z zaokroženim povzetkom in komentarjem ugotovitev o planetarnem ekosistemskem kroženju (planetarni biogeokemični krogi) in vprašanju ogroženosti zemeljske atmosfere nakazal nujnost upoštevanja povezanosti lokalnega in globalnega onesnaževanja okolja.

Z izjemo prispevka V. Klemenčiča (1972) je za prvo polovico 70. let 20. st. opazna določena zamuda Oddelka in celotne slovenske geografije glede raziskovanja konkretnih primerov degradacije okolja ali njegovih sestavin v posameznih slovenskih pokrajinah. Tako je že Radinja (1972) opozoril na določeno zaostajanje geografske znanosti in to prav na okoljskem področju, kjer bi se lahko kot celota najbolj uveljavila. P. Mihevc (1972) pa je kritično ugotavljal, da bi morali razen raziskovanja specifične problematike degradacije okolja oziroma varstva okolja delovno področje varstva človekovega okolja in narave takoj vključiti tudi v vzgojo in izobraževanje.

Zato je bila na mestu zakrbljenost Radinje $(1974,111)$, da v geografijo vdirajo različni izrazi, zlasti iz ekologije, ustrezna geografska terminologija pa je potisnjena na obrobje. Po njegovem mnenju naj bi prav (pre)velika specializacija takratne slovenske geografije preprečevala, da bi se naša geografija bolj angažirala pri problematiki varstva okolja (Radinja 1974, 117). Tudi sicer je podčrtoval, da je $\mathrm{v}$ razliko od kompleksnih geografskih raziskav s stališča koncepta enotne geografije težje nakazati naloge z vidika specializirane geografije (Radinja 1974, 118), čemur je pritrdila $\mathrm{z}$ vidika prakse tudi Kokoletova (1974). Vsekakor so zgodnji teoretično metodološki temelji, ki sta jih vztrajno dograjevala Ilešič in Radinja (kasneje tudi kon- 
kretno vsebinsko) med drugim odločilni za nastanek in razvoj učnega predmeta in katedre za varstvo geografskega okolja na Oddelku.

Gams (1975) pa je na drugi strani opozoril, da se mora geografija z lastnim metodološkim in širšim pristopom vključiti v sodobno problematiko raziskovanja ekotopov in pokrajinske ekologije v Sloveniji in tako skupaj s konkretnim vzorčnim preizkusom (Gams, Lovrenčak in Plut 1978) postavil temelje za kasnejši izobraževalni in raziskovalni razvoj pokrajinske ekologije na Oddelku. S številnimi konkretnimi, zlasti fizičnogeografsko obarvanimi okoljevarstvenimi in naravovarstvenimi vsebinami v znanstveni monografiji Kras - zgodovinski, naravoslovni in geografski oris, je Gams (1974) vsebinsko prepričljivo nakazal različne možnosti vključevanja okoljskih poudarkov v posamezne geografske discipline in posebne, kraške pogoje sodobnega onesnaževanja okolja. Med pomembnimi prispevki geografov izven Oddelka pa je potrebno omeniti vsaj prispevka Ravbarja in Orožna Adamiča (1978) in Ravbarja (1976; 1977) o varstvu narave ter problemih okolja ob načrtih za hidroelektrarne v Zgornjem Posočju ter geografske vidike takrat in tudi še danes aktualnega problema t.i. črnih gradenj (Ravbar, 1975; 1978).

Na stežaj odprta 'okoljska' vrata so slovensko geografijo v prvi polovici 70. let 20. st. glede konkretnih geografsko kompleksnih del z redkimi izjemami kar nekako presenetila! Hkrati pa velja podčrtati, da je v izjemno odmevni in že leta 1972 (v istem letu kot je bila prva svetovna konferenca o človekovem okolju v Stockholmu!) objavljeni Zeleni knjigi o ogroženosti okolja v Sloveniji (sodelovanje M. Orožna Adamiča pri obsežnem interdisciplinarem seznamu literature in virov) tudi prispevek V. Klemenčiča (1972) o pereči problematiki stihijske deagrarizacije in urbanizacije ter obsežni pozidavi za kmetijstvo dragocenih ravninskih in dolinskih območij Slovenije, kar samo po sebi priča o potrebnosti geografskih raziskav v sicer interdisciplinarnem preučevanju problemov življenjskega, človekovega okolja.

Živahnim in delno polemičnim, uvodoma upravičeno prednostno teoretično-metodološkim razpravam prve polovice 70 . let 20. st., so sledile konkretne geografske raziskave na področju onesnaženosti in varstva geografskega okolja takratnih in kasnejših sodelavcev Oddelka. Med članki slovenskih geografov, ki so na okoljskem polju delovali izven Oddelka, je z vsebinskega in metodološkega vidika pomembna raziskava o problematiki odpadkov v Ljubljani (Orožen Adamič in Pleskovič 1975). Jeršič (1976) pa je geografsko, pokrajinsko zasnovane varovalne poudarke metodološko in vsebinsko inovativno vnesel v zasnove uporabe prostora za rekreacijo v Sloveniji.

Radinja je opozoril na pomen kasneje zelo aktualne problematike onesnaževanja pokrajinske sfere z nafto (1977) ter problematiko nastajanja umetnih jezer po svetu (1978b). Špesova (1977) je opredelila geografske (fizično- in družbenogeografske) dejavnike onesnaženosti Celja, Černe (1977) preučil degradacijo okolja v Velenjski kotlini s pomočjo faktorske analize, s pomočjo fizičnogeografskih in okoljskih kriterijev pa je bila opravljena valorizacija kopališč Koprskega Primorja (Plut 1977). V reviji Naše okolje so bili leta 1978 objavljeni kar štirje prispevki takratnih in kasnejših, zlasti mlajših sodelavcev Oddelka (starih manj kot trideset let), ki so imeli pred objavo odmevne in polemične referate na predhodnem jugoslovanskem simpoziju o geografskih problemih življenjskega okolja. Radinja (1978a) je s sebi lastno geografsko kompleksnostjo in empirično prepričljivostjo prikazal pokrajinske značilnosti industrializacijske onesnaženosti v Sloveniji, generacija '50, torej Špesova (1978), Černe 
(1978) in Plut (1978) pa so s pomočjo funkcijskega regionalnogeografskega pristopa (delno tudi matrične obdelave) prikazali moč in nemoč (enotne) geografije pri preučevanju okoljske problematike geografsko zaokroženih območjih degradacije okolja na primerih Celjske kotline, Velenjske kotline (Šoštanja) in Koprskega Primorja. Poudariti velja, da je v navedenih regionalnogeografskih okoljskih raziskavah onesnaženih geografskih območjih bilo raziskano stanje vseh pokrajinotvornih sestavin in ključni vzroki (fizično- in družbenogeografski) obsega in intenzivnosti degradacijskih procesov, v ozadju pa so bili konkretni predlogi za okoljsko sanacijo in okolju prilagojeno načrtovanje razvoja.

Skupaj z drugimi objavljenimi geografskimi raziskavami v navedeni številki Našega okolja (Lah 1978; Domitrovič Uranjek 1978; Orožen Adamič 1978) je geografija drugim strokam, javnosti in politiki po mnenju pisca z manjšo zamudo, a dovolj prepričljivo prikazala geografski metodološki in vsebinski okoljski potencial in upravičenost ne le specializiranih, temveč tudi vsebinsko bolj zaokroženih okoljskih vsebin o vzrokih (naravnih in družbenih) in zlasti o pokrajinskih posledicah različnih degradacijskih procesov. Radinja (1979) pa je na primeru onesnaženosti slovenskih rek in njenih pokrajinskih značilnosti argumentirano dokazal, da lahko slovenska geografija kompleksno in večplastno, s pomočjo celostnega pristopa osvetli degradacijsko tematiko posamezne fizičnogeografske sestavine, vključno z njeno tipologijo onesnaženosti (na primeru vodnih tokov).

$\mathrm{Na}$ osnovi trdnih teoretičnih temeljev pionirjev slovenske okoljske geografije prve polovice 70 . let 20. st. so empirično zasnovane študije zlasti druge polovice 70 . let 20 . st. članov Oddelka in drugih geografov le uspele usvrstiti tudi geografijo med pomembne znanstvene discipline, ki lahko suvereno, z lastnim metodološkim pristopom sodelujejo pri raziskovanju interdisciplinarne problematike življenjskega okolja. Potrjena je bila delovna hipoteza, da se slovenske pokrajine in pokrajinotvorni elementi zaradi različnih samočistilnih sposobnosti različno odzivajo na obremenjevanje okolja, kar je potrebno upoštevati pri načrtovanju regionalnega in prostorskega razvoja. In ne nazadnje - empirično je bilo prepričljivo dokazano, da je tudi socializem okoljsko zelo destruktiven in celo ogroža samo zdravje urbanih prebivalcev (Špes 1977; 1979).

V obdobju 1959-1979 so bili na Oddelku objavljeni naslednji teoretično in vsebinsko ključni prispevki okoljske geografije:

- teoretično-metodološki: Ilešič (1959; 1962; 1964; 1972; 1973; 1979), Radinja (1972; 1974), Gams (1975), Jeršič (1976);

- varstvo narave: Gams (1968; 1969), Radinja (1967);

- onesnaženost in varstvo človekovega okolja v Sloveniji in pokrajinah: V. Klemenčič (1972), Gams (1974), Špes (1977; 1978; 1979), Černe (1977; 1978), Plut (1977; 1978), Radinja (1978a; 1979);

- onesnaženost in varstvo planetarnega okolja: Gams (1972), Radinja (1977; 1978b).

V prvem obdobju okoljske geografije Oddelka (in tudi celotne slovenske geografije) je bila osrednja pozornost namenjena snovanju solidnega teoretično-metodološkega temelja za empirične raziskave in prvim sinteznim poskusom geografskega raziskovanja konkretnih problemov varstva narave in okolja. Sodobna problematika varstva geografskega okolja je slo- 
vensko geografijo ujela sredi vročičnih in ideološko obarvanih razprav o enotnosti ali dualizmu v geografiji. Pereča naravovarstvena in okoljevarstvena problematika je tudi slovensko geografijo po svoje 'prisilila', da je v nasprotju z dogmatsko inačico marksizma in še bolj odločno zagovarjala nujnost enotne geografije. Onesnaženost geografskega okolja in njenih sestavin se je obravnavala kot pokrajinsko rezultanto, ki je skupna posledica prepletenega delovanja in součinkovanja fizičnogeografskih in družbenogeografskih značilnosti, ločena obravnava torej za geografijo kot povezovalno znanost ni ustrezni, kompleksni odgovor. Kasnejši razvoj slovenske okoljske geografije pa je potrdil tudi potrebo po bolj podrobni, delno specializirani obravnavi vzrokov in predvsem pokrajinskih posledic onesnaževanja posamezne sestavine geografskega okolja (zrak, voda, prst itd.).

Lahko zaključimo, da je v 60., zlasti pa v 70. letih 20. st., slovenska geografija, tudi na osnovi številnih okoljskih prispevkov članov Oddelka ustvarila dovolj solidne temelje za nadaljnji metodološki in vsebinski napredek v raziskovalni in vzgojno-izobraževalni okoljevarstveni sferi. Z veliko težavo je geografija vsaj delno 'ubranila' osrednje okoljsko področje pred vdorom bližnjih znanosti (zlasti krajinske arhitekture) na geografsko tradicionalno vsebinsko polje, ki je s problematiko intenzivnega antropogenega preoblikovanja okolja postalo širše raziskovalno privlačno, delno tudi modno. Precejšen del slovenske geografije, zlasti družbena (socialna) geografija, se je v 60. in 70. letih 20. st. nahajala v občutljivem obdobju izrazite specializacije, delno tudi na račun zanemarjanja ali celo podcenjevanja pomena fizičnogeografskih dejavnikov družbenega razvoja, rabe prostora in preobrazbe slovenskih pokrajin. S tega vidika je potrebno ocenjevati tudi občasno polemične, a z vidika geografije kot kompleksne znanosti upravičene in po mnenju pisca seveda dobronamerne pozive S. Ilešiča za enotno geografijo, saj bi zgolj enostranske družbeno- ali fizičnogeografske specializacije, brez regionalnogeografskih raziskav, poudarkov in vsebin, lahko postopoma ogrozile sicer trajno občutljivo 'mostovno' mesto geografije v sistemu znanosti na Slovenskem. Kasnejši razvoj tudi slovenske socialne geografije pa črnogledih napovedi S. Ilešiča ni potrdil.

Ponovno aktualna kompleksna problematika razmerja človek - okolje je torej slovensko geografijo ujela delno nepripravljeno, o čemer priča razen časovnega zaostanka v izdelavi kompleksnih, regionalnogeografsko zasnovanih preučevanj območij izrazitejše pokrajinske degradacije tudi več ali bolj uspešno holistično zasnovano raziskovanje ne-geografov na sicer tradicionalnem geografskem raziskovalnem 'vrtičku'. Samokritično je potrebno še dodati, da so obenem izdelane regionalnogeografske raziskave pokrajinske degradacije sicer celovito predstavile stanje in pretekle trende degradiranih pokrajinotvornih sestavin, a zgolj obrobno in preveč splošno nakazovale potrebne načrtovalske ukrepe za reševanje ugotovljenih degradacijskih problemov. 'Ekologizacija' geografije Oddelka je v uvodnem obdobju potekala kot določena vrsta specializacije in praviloma ni globlje segla $\mathrm{v}$ druge geografske veje oziroma učne predmete, kar zlasti velja za ekonomsko geografijo.

$\mathrm{Na}$ drugi strani pa je slovenska geografija tudi sama delno posegla na aktualno interdisciplinarno polje človek (družba) - okolje in narava, kar je povzročilo tudi nekaj terminološke zmede in nedoslednosti, pa tudi dvomov. Hkrati je tudi delno tvegano poseganje v robna okoljska polja geografom omogočilo, da so v številnih primerih postali prepoznavni in suvereni nosilci interdisciplinarnih okoljskih raziskav, zlasti v okviru univerzitetnega Inštituta za 
geografijo. Daljše obdobje pa je bilo potrebno, da je 'ekologizacija' geografije bolj poglobljeno in funkcijsko segla na področje šolske geografije, v geografske učbenike za osnovne in srednje šole, pa tudi v univerzitetne geografske učbenike.

\section{ORIS RAZISKOVANJA NA PODROČJU OKOLJSKE GEOGRAFIJE ODDELKA ZA GEOGRAFIJO LJUBLJANSKE FILOZOFSKE FAKULTETE $V$ OBDOBJU 1980-2009}

V obdobju 1980-2009 se je na osnovi razvejanih geografskih 'okoljskih korenin' na Oddelku in v celotni slovenski geografiji pospešeno nadaljeval razvoj in širitev polja raziskovanja okoljske geografije, o čemer pričajo številne domače in tuje objave, sodelovanje na tujih in domačih posvetih, monografije in druga knjižna dela, številni domači in tuji raziskovalni projekti, sodelovanje v javnosti, množica zagnanih mlajših geografov, ki več kot uspešno nadomeščajo že delno utrujene okoljske 'geografske maratonce'. Prostor in čas žal ne dopuščata celotnega navajanja, še manj podrobnega komentiranja in navajanja številnih raziskovalnih projektov, člankov, monografij. Le na osnovi subjektivnega, osebnega izbora metodološko in vsebinsko morda osrednjih znanstvenih in strokovnih prispevkov sodelavk in sodelavcev Oddelka v obdobju po letu 1979 pa lahko zaslutimo obrise vse bolj razvejanega celotnega geografskega okoljskega opusa slovenske geografije.

Mavrično vsebinsko okoljsko polje zgolj po mnenju pisca nekaterih ključnih izbranih prispevkov sedanjih in nekdanjih članov Oddelka za geografijo v obdobju 1980-2009 (prva polovica leta) lahko zelo okvirno (številni prispevki so vsebinsko večplastni in jih težko uvrstimo v posamezno skupino!) razvrstimo v naslednja področja preučevanja:

- teoretično-metodološko okoljsko polje: Radinja (1980a; 1987), Bat in sod. (1985), Plut (1991; 2004b; 2005), Špes (1998; 2000; 2007b), Lampič in Smrekar (1998), Brečko Grubar (1999), Kušar (2001), Vintar Mally (2006; 2007a), Lampič in sod. (2007), Natek (2007);

- onesnažena (degradirana) geografska območja: Radinja (1983), Plut (1987; 2004c);

- okoljska preučevanja mest: Špes in Plut (1982), Špes (1984; 2009), Ravbar in Plut (1999), Špes in sod. (2000; 2001; 2002a), Cigale in sod. (2006), Rebernik (2007);

- okoljska preučevanja podeželja in kmetijskega onesnaževanja: Radinja (1996; 1997), Brečko Grubar in sod. (1996), Lampič (2000b; 2007a; 2008), Lampič in Potočnik Slavič (2007), M. M. Klemenčič, Lampič in Potočnik Slavič (2008);

- problematika varstva narave in varovanih območij: Kunaver (1981; 2007), Jeršič (1989), Lampič (2007b), Lampič in Mrak (2007a; 2007b; 2008), Mrak (2007b; 2008), Plut in sod. (2008);

- onesnaževanje pokrajinotvornih sestavin: Radinja (1980b; 1984; 1988a; 1988b), Špes (1987), Plut (1988), Plut, Špes in Brečko Grubar (2002), Brečko Grubar (1996; 1998a; 1998b; 2007; 2009), Repe (2002; 2009), Cigale in Lampič (2003);

- okoljska preučevanja dejavnosti (brez kmetijstva) kot virov obremenjevanja okolja: Gosar (1987; 1993), Jeršič (1989; 2001), Špes (1990), Cigale (2007), M. Ogrin (2007; 2008), Mrak (2007a); 
- pokrajinskoekološka preučevanja: Plut (1981), Gams (1986), Natek (1996), Lovrenčak (1997; 2003), Špes (2000; 2007a);

- planetarni in evropski okoljski problemi: Plut (2004a), Vintar Mally (2007b);

- podnebne spremembe: Gams (1994; 1998), D. Ogrin (2003; 2009);

- trajnostni, sonaravni razvoj: Plut (1995; 2006; 2007), Špes in sod. (1995), Natek (1999), Lampič (2000a), Vintar Mally (2002; 2003a; 2003b; 2005; 2009), Gosar in Jurinčič (2003), Berdavs, Gosar in sod. (2006), Špes (2008);

- okoljsko geografsko izobraževanje: Kunaver (1989; 1996; 1997), Resnik Planinc (2006; 2008a; 2008b).

Za razliko od prvih dveh desetletjih razvoja slovenske okoljske geografije na Oddelku so se teoretično-metodološke raziskave v 80 . letih 20. st. najprej preusmerile iz načelnih problemov in utemeljevanja potrebe po kompleksnemu geografskemu raziskovanju geografskega okolja $\mathrm{z}$ vidika enotne geografije $\mathrm{k}$ bolj sistematični izdelavi zelo konkretnih geografskih navodil za raziskovanje posameznih okoljskih problemov in degradacijskih dejavnosti (Bat in sod. 1985): preučevanje problematike industrijskega obrata, zadruge, odlagališč odpadkov, lokalnega onesnaževanja zraka, kmetijskega obremenjevanja, določanja pokrajinskoekoloških enot, izbora primernih lokacij za gradnjo malih hidroelektrarn, vprašalniki o odnosu prebivalcev do okolja itd. S pomočjo natančnih geografskih navodil, ki so bila celostno zasnovana, se je zelo povečalo zanimanje študentov geografije, dijakov, udeležencev številnih mladinskih raziskovalnih taborov in drugih za bolj poglobljene geografske okoljske raziskave, ki so potekale v številnih, geografsko različnih območjih Slovenije.

Za razliko od prispevkov začetnega obdobja slovenske okoljske geografije so začeli prevladovati prispevki, ki so hkrati metodološki in aplikativni, v ospredju so bili torej konkretni preizkusi uporabnosti geografskih metodoloških zasnov. Posamezni člani Oddelka (D. Radinja, D. Plut) so se v 80. letih 20. st. aktivno vključili v številne okoljske raziskovalne projekte takratnega univerzitetnega Inštituta za geografijo, ki jih je vodila M. Špes. Opravljene so bila kompleksno in regionalnogeografsko usmerjene raziskave nekaterih najbolj degradiranih območij Slovenije (Zasavje, Zgornja Mežiška dolina, Zgornjesavska dolina). Za razliko od specialističnih raziskav so bili raziskani vsi onesnaženi pokrajinotvorni elementi, povezanost med človekovim delovanjem in naravnimi značilnostmi, pa tudi odnos prebivalstva do onesnaženega okolja. V ospredju je bil geografsko-diagnostični pogled, manjša pozornost pa se je še vedno namenjala prognostičnemu vidiku, ki je bil bolj prisoten v nekaterih negeografskih raziskovalnih projektih.

$Z$ vidika potrebne reintegracije slovenske geografije je torej v 80. letih 20. st. na okoljskem polju Oddelka prišlo do številnih pozitivnih raziskovalnih premikov, kar se je kasneje še okrepilo. Okoljska oddelčna in siceršnja slovenska geografska raziskovalna praksa je torej konkretno in empirično podkrepljeno zavrnila nekatera najbolj črnogleda razmišljanja S. Ilešiča o blodenju po poteh razkrajajočega geografskega dualizma. A obenem velja tudi v tem geografskem ‘okoljskem' trenutku pritrditi razmišljanju Radinje (1987), da bi veljajo še okrepiti sicer prisotne napore za večjo uveljavitev kompeksne, regionalne, problemske ali kakšne druge geografije in z njo povezanega in prepotrebnega skupnega dela. 
Metodološko dograjevanje geografskega raziskovanja posamezne okoljsko obremenjujoče dejavnosti (vir obremenjevanja geografskega okolja) v obdobju 1980-2009 lahko zelo nazorno spremljamo npr. pri raziskovanju okoljskih razsežnosti kmetijstva in podeželja, od uvodnih navodil za raziskovanje (Radinja 1980a) do kompleksnih, kvantitativno zasnovanih vprašalnikov in izvedenih raziskovalnih modelov o agrarnem (pre)obremenjevanju pokrajinskega okolja (Radinja 1996; 1997; Lampič 2000b) ter modeliranja strategij razvoja slovenskega podeželja in geografskih območij, ob upoštevanju okoljskih, sonaravnih izhodišč (M. M. Klemenčič, Lampič in Potočnik Slavič 2008; Lampič 2009). Podobno velja za okoljsko zasnovane raziskave problematike slovenskih mest, kjer se je nadaljevalo in poglobilo regionalnogeografsko zasnovano raziskovanje degradacijskih urbanih problemov, z večjim poudarkom tudi na socialnogeografski problematiki (Špes in Plut 1982; Špes 1984; 1998; Špes in sod. 2000) in v zadnjem obdobju tudi na trajnostno sonaravnih razsežnostih urbanega razvoja (Cigale in sod. 2006; Lampič in sod. 2007; Plut 2007; Rebernik 2007).

Preučevanje onesnaževanja posameznih pokrajinotvornih sestavin okolja in vzrokov za njihovo degradacijo se je osredotočilo zlasti na konkretne raziskave onesnaženosti zraka (in hrupa) (Špes 1987; Radinja 1988a; Cigale in Lampič 2003; M. Ogrin 2008), vode (Radinja 1984; 1988b; Plut 1988; Brečko Grubar 1996; 2009) in prsti (Repe 2002). Z vidika pokrajinsko, kompleksno zasnovanega geografskega raziskovanja posameznega pokrajinotvornega elementa je kasnejšim podobnim raziskavam (tudi študentom pri izdelavi diplomskih in drugih del) kot metodološki in vsebinski zgled služil prispevek Radinje (1988b) o širši degradacijski problematiki Blejskega jezera z vidika njegove pokrajinske strukture. Glede na perečo problematiko predvsem onesnaževanja vod in zraka bi pričakovali še večjo geografsko raziskovalno zanimanje za navedeno problematiko, kar v določeni meri velja tudi za aktualno temo podnebnih sprememb in njihovih pokrajinskih posledic (Gams 1994; 1998; D. Ogrin 2003; 2009). Prav tako je bila dokaj skromna pozornost namenjena planetarnim in evropskim razsežnostim onesnaževanja okolja in z njim povezanimi socialnimi in gospodarskimi problemi (Plut 2004a; Vintar Mally 2007b), kar pa ne velja za nadaljevanje razvejanega geografskega preučevanja okoljskih vidikov razvoja turizma in rekreacije (Gosar 1987; Jeršič 1989; 2001; Cigale 2007; Mrak 2007a; 2007b).

$\mathrm{V}$ nasprotju s kompleksnim geografskim raziskovalnim potencialom in tradicijo se je onesnaženim oziroma degradiranim geografskim območjem Slovenije namenila le obrobna pozornost, delno tudi zaradi že omenjenega bolj poglobljenega raziskovanja onesnaževanja slovenskih mest. Nadaljevalo pa se je raziskovanje na področju pokrajinske ekologije s poudarkom na raziskavah pokrajinskoekološke sestave (Plut 1981; Natek 1996; Lovrenčak 1997; 2003) in urbanih ekosistemov (Špes 2007a; 2009).V širše pojmovanem raziskovalnem polju pokrajinske ekologije se je izdelal izvirni raziskovalni model ranljivosti okolja, ki na osnovi predhodne pokrajinskoekološke členitve obravnavanega območja kljub določenim objektivnim omejitvam omogoča okvirno, sintezno in medsebojno primerljivo raziskovanje obsega ter stopnje pokrajinske ranljivosti posameznih elementov in okolja kot celote (Špes in sod. 2002b).

Klasično zasnovano preučevanje varstva narave se je v zadnjih letih razširilo v trajnostno sonaravno raziskovanje specifičnosti regionalnega razvoja zavarovanih območij (Lampič in Mrak 2008; Plut in sod. 2008). Tudi na navedenem raziskovalnem področju okoljske 
geografije Oddelka se kaže vse bolj jasno postopno širjenje v preteklosti z vidika varstva narave zasnovanih varovalnih vsebin $\mathrm{k}$ varovalno-razvojnemu raziskovanju. Postopoma se razvijajo integralni geografski trajnostno sonaravni raziskovalni modeli in sistemi večplastnih (gospodarski, družbeni in okoljski) kazalcev trajnostnega regionalnega razvoja (Plut 1998; 2004b; 2005; 2007; Špes 2000; 2008; Vintar Mally 2002; 2006). Podoben trend postopnega širjenja okoljskih vsebin se kaže tudi pri pouku geografije na različnih ravneh (Kunaver 1989; 1996; Resnik Planinc 2008a).

\section{PRIHODNJI VERJETNI IZZIVI NA PODROČJU OKOLJSKE GEOGRAFIJE ODDELKA ZA GEOGRAFIJO LJUBLJANSKE FILOZOFSKE FAKULTETE}

Še vedno naraščajoča aktualnost in večplastnost (prepletene ekonomske, družbene in okoljske razsežnosti) tudi prostorskih razsežnosti lokalnih, regionalnih in planetarnih okoljskih problemov uvodoma zahteva ne le sicer koristno in kritično oceno dosedanjih uspehov in neuspehov na okoljskem geografskem polju, temveč zlasti ponovno poglobljen razmislek o predmetu, vsebini okoljske geografije v Sloveniji v delno spremenjenih sodobnih razmerah. $\mathrm{Za}$ razliko od 70 . let 20. st. nam na srečo ni več potrebno utemeljevati potrebe po enotni geografiji, saj se je njena družbena potreba verjetno prav na okoljskem polju z vso silovitostjo v praksi najbolj nazorno potrdila. Geografsko samokritično lahko dodamo: potrebnost kompleksnega, pretežno regionalnogeografskega pristopa potrjujejo tudi številne ne-geografske raziskave, ki nas tudi dodatno opominjajo na nevarnosti pretiranega geografskega zanemarjanja omenjene, vsebinsko brez dvoma ene od osrednjih geografskih raziskovalnih polj. Prav bolj jasna opredelitev predmeta geografskih raziskav na področju okoljske geografije v spremenjenih razmerah odnosa človek (družba) - okolje, narava v obdobju pričakovanega postopnega uveljavljanja trajnostno sonaravne civilizacijske paradigme na različnih prostorskih ravneh je verjetno prvi potrebni korak pri iskanju zapletenih odgovorov in želenih vsebinskih usmeritev. Zaželeno bi bilo, da se slovenska geografija in ključne geografske veje, zlasti regionalna geografija, bistveno bolj aktivno vključijo v raziskovanje širše, troplastno (ekonomsko, družbeno in okoljsko) pojmovanega (ne)blagostanja in širše pojmovane kakovosti življenja $v$ različnih slovenskih regijah, pokrajinah. In ne zanemariti strateško pomembnega terminološkega polja in še vedno prisotnih in vedno novih geografskih okoljskih pojmovnih zadreg, ki jih je sicer v veliki meri že odpravilo vztrajno delo Laha (2002) in urednikov ter sodelavcev kakovostnega Geografskega terminološkega slovarja (2005).

Radinja (1974) je zelo zgodaj opozoril, da naj geografija poudarja splošni problem življenjskega okolja in iskanje poti do ustreznega ravnovesja med zahtevami, ki jih na eni strani prinašajo prebivalstvena rast, tehnični napredek in težnja po višjem življenjskem standardu, ter na drugi strani možnostmi, da se ohrani biološko zdravo in estetsko sprejemljivo okolje. Geografija lahko s konkretnimi kompleksnimi regionalnimi analizami največ prispeva k praktičnemu vzpostavljanju občutljivega in dinamičnega pokrajinskega ravnovesja. Tako ostaja aktualno regionalnogeografsko zasnovano preučevanje geografskega okolja, njegovo varovanje in izboljšanje. Le-tega geografija obravnava kot splet naravnih pojavov in antropogenih 
elementov v prostorski stvarnosti, v katerem veljajo tako naravne kot družbene zakonitosti razvoja, ki jih je potrebno upoštevati pri varovanju (geografskega) okolja. Ne glede na to, da smo ljudje sami sestavni del narave, pa pripada človeški družbi vloga glavnega in zavestnega gibala preobrazbe prirode. Prav zaradi teh tesnih vezi moramo pojmovati geografsko okolje v najširšem smislu kot naravno okolje, antropogeno preoblikovano naravno okolje (obdelovalne površine, gojeni gozd, urejene vodne razmere) in pretežno antropogeno ali tehnogeno okolje (naselja, predvsem mesta, industrijske in prometne naprave) (Ilešič 1979, 320-321).

Geografijo zanimajo tiste naravno- in družbenogeografske značilnosti pokrajin (regij, območij), ki so pomembne za razlago degradacije okolja in njegovih sestavin (Špes 1998). Degradacija geografskega okolja je preobrazba okolja s porušenim naravnim ravnovesjem zaradi prekomernega obremenjevanja ali/in zmanjševanja samočistilne sposobnosti okolja (pokrajine) in njegovih sestavin. Širše pojmovan osnovni predmet preučevanja degradacije geografskega okolja torej obsega zlasti:

- izčrpavanje naravnih virov (neobnovljivih in obnovljivih, zmanjševanje odprtega prostora) ter zmanjševanje samočistilnih in drugih zmogljivosti okolja;

- antropogene spremembe biogeokemičnega kroženja elementov in vode ter nastanek novih krogov umetnih snovi ter njihov vpliv na kakovost življenja, razvojne možnosti;

- onesnaženost okolja in njegovih sestavin - zraka, vode, prsti, vegetacije in reliefa na lokalni, regionalni in planetarni ravni.

Geografska raziskovanja okolja naj bi torej vključevala degradacijske procese in stanje okolja ter varstvo, varovanje geografskega okolja kot poudarjanje pomena ohranjanja, izboljšanja kakovosti in preprečevanje njegove degradacije kot celote ter njegovih sestavin (naravnih in antropogenih). V širšem pomenu naj bi torej predmet geografskega raziskovanja okolja razen degradacije geografskega okolja vključeval tudi varovanje (zaščito) naravnih (okoljskih) virov, pokrajinske in biotske raznovrstnosti, narave, naravne in kulturne dediščine (Plut 1998).

Temeljna načela varstva geografskega okolja so:

- celovita sanacija degradiranih pokrajin in pokrajinotvornih sestavin (voda, zrak itd.);

- preprečevanje nastajanja novih virov in območij onesnaževanja;

- smotrno gospodarjenje z naravnimi (okoljskimi) viri;

- gospodarski razvoj (napredek) in pokrajinska raba v okviru omejitev geografskega okolja (prostorskih, surovinsko-energetskih in samočistilnih);

- trajno ohranjanje narave, naravnih (okoljskih) virov in pokrajinske raznovrstnosti za bodoče generacije.

Celostno razumevanje in preučevanje degradacije in varstva geografskega okolja potrjuje smisel geografije kot kompleksne vede ter njenega osrednjega predmeta - geografskega okolja (pokrajine) (Radinja 1974, 38). Varstvo okolja, številnih naravnih potencialov pa je v sodobnem svetu vitalnega pomena ne le za kakovost našega življenja, temveč tudi za preživetje prihodnjih generacij (Vovk Korže 1997; 2002).

Po mnenju pisca naj bi bile prihodnje osrednje okoljske raziskave in izobraževanje na Oddelku razen prepotrebnih temeljnih teoretično-metodoloških raziskav (s poudarkom na 
dograjevanju integralnega raziskovalnega geografskega okoljskega modela in sistemu zlasti sinteznih okoljskih kazalcev) in funkcijsko zasnovanega vključevanja spoznanj geografije naravnih nesreč (s poudarki zlasti na antropogenih vplivih na njihov obseg in intenzivnost) ključno usmerjene v naslednja osrednja, kompleksno in zlasti regionalnogeografsko prednostno zasnovana vsebinska polja:

- ekološka geografija (s humano ekologijo);

- geografija okoljskih virov in geografija sonaravnega razvoja (napredka).

1. Ekološka geografija - raziskave in celoten razvoj ekološke geografije (in humane ekologije) kot potrebnega teoretično-metodološkega in vsebinskega dograjevanja, širjenja dosedanjih učnih predmetov Varstvo geografskega okolja in Pokrajinska ekologija na Oddelku naj bi osvetlile večplastno soodvisnost človeka z njegovim naravnim in antropogeno preoblikovanim okoljem v geografsko in ekološko mozaični Sloveniji. V ospredju naj bi bil sintezni, a aplikativni, pretežno regionalnogeografski (vključuje pa tudi spoznanja drugih vej fizične in družbene geografije) metodološki in vsebinski pristop, ki naj bi se žariščno usmerjal na celostno zasnovano preučevanje različnih prostorskih, pokrajinskih posledic preobrazbe (ožje - degradacije) geografskega okolja pokrajinskih tipov Slovenije, na kompleksno, fizično- in družbenogeografsko sintezno zasnovano pokrajinsko diagnozo. Še večjo pozornost bi bilo potrebno nameniti odzivom človeka na spremembe okolja, vplivu okolja in njegovih degradiranih sestavin na kakovost bivanja, kvaliteto življenja v različno degradiranih geografskih območjih Slovenije. Avtor se namreč strinja z mnenjem Marsha in Grosse $(2002,14)$, da naj bo ekološka geografija usmerjena v raziskovanje različnih oblik degradacije okolja, kakovost okolja in življenjskih razmer. Vzročno-posledično naj torej geografija raziskuje različne sestavine okolja slovenskih pokrajin, regionalne razsežnosti ključnih okoljskih problemov, pokrajinske učinke človekovih posegov v različne pokrajine, pokrajinske tipe, pokrajinske ekosisteme, večplastne vplive na širše pojmovano kvaliteto življenja in blagostanje.

V slovenskih geografskih razmerah pa naj bi članice in člani Oddelka posebno pozornost namenili ne le različnim gonilnim silam in stanju degradacije okolja in njegovih pokrajinotvornih sestavin, temveč tudi specifičnim regionalnim samočistilnim zmogljivostim, (pokrajinski) ranljivosti okolja in odzivu prebivalcev na okoljsko problematiko. V mozaičnem poselitvenem vzorcu naj bi raziskali tiste dejavnosti rabe prostora, ki degradirajo naravne (bolje - okoljske) vire in okolje in s tem zmanjšujejo v dosedanjih geografskih raziskavah skoraj prezrte in vse bolj ogrožene ekosistemske storitve (morda bi bilo geografsko umestno uporabljati pojem pokrajinske ali okoljske storitve), zmogljivosti oskrbe življenja sedanjih in prihodnjih generacij.

V obdobju pričakovanega naraščajočega pomena ekocentrične etike naj bi tudi slovenska okoljska geografija ponovno večjo pozornost namenila preučevanju ohranjanja narave, varovanim območjem in njihovim, praviloma še neovrednotenim varovalno-razvojnim potencialom. Varstvo geografskega okolja in narave v širšem pomenu je eden od temeljnih pogojev trajnostnega sonaravnega razvoja (gospodarski napredek v okviru omejitev okolja), saj omogoča zanesljivost zadovoljevanja potreb sedanje generacije brez ogrožanja življenja prihodnjih generacij ter drugih vrst. Zato je potrebno razen pokrajinskih učinkov posegov opozarjati tudi na trende, torej osnovne smeri pokrajinskih procesov v Sloveniji in njenih regijah. 
Potrebno bi bilo izdelati regionalne in državno karto tipologije pokrajinske ranljivosti (pokrajinske občutljivosti in pokrajinske obremenjenosti) in na tej osnovi tipologijo sprejemljivih okoljskih posegov in sonaravne pokrajinske rabe, opredeliti pokrajinske ekosisteme oziroma pokrajinskoekološke enote, izluščiti območja sanacije degradiranega okolja ter na drugi strani območja strogega varovanja okolja, narave.

Opozoriti pa je potrebno na določeno previdnost pri sicer potrebnem obsežnejšem geografskem raziskovanju in aktivnejšem sodelovanju pri širokih vsebinah humane ekologije, kjer bi moralo biti v ospredju prepoznavanje in večplastno vrednotenje geografskih součinkov preoblikovanja okolja na kakovost življenja. Vsekakor pa bi bilo napačno, da se geografija odreče možnostim in svojemu specifičnemu raziskovalnemu potencialu na interdisciplinarnih vsebinskih temah razmerja človek - okolje, zlasti možnostim sinteznega raziskovanja (povratni loki), koordinacije in vključevanja socialnogeografskih, pokrajinskoranljivostnih in regionalnogeografskih razsežnosti.

Izpostaviti bi veljajo potrebo po poglabljanju, za Oddelek dejansko že tradicionalnega in odmevnega, geografskega raziskovanja odnosa prebivalcev do onesnaževanja okolja, pokrajinskoekoloških členitev in raziskovanja samočistilnih značilnosti pokrajinotvornih sestavin v okviru uporabnega modela ranljivosti okolja, ki npr. niso vključena v sicer uporabne raziskovalne modele Evropske agencije za okolje (model DPSIR).

2. Geografija okoljskih virov in geografija sonaravnega razvoja - vsebini predlagane geografije okoljskih virov in geografije sonaravnega razvoja se navezujeta na vsebino ekološke geografije, v raziskovalno središče pa postavljata dvoplastno, ne zgolj razvojno, temveč tudi varovalno vrednotenje potenciala naravnih, okoljskih virov in okoljske razsežnosti prostorskega ter regionalnega razvoja, ki so bile desetletja postavljene na raziskovalno in vrednostno obrobje. Obe vsebini širše pojmovane okoljske geografije torej izhajata iz predpostavk trajnostno sonaravne paradigme, ki civilizacijski napredek (materialno, družbeno, okoljsko in etično) ocenjuje širše, torej tudi z vidika trajnostnega ohranjanja pogojev kakovosti življenja človeštva in drugih vrst, ne pa zgolj na osnovi rasti BDP, torej materialne stranice blagostanja. Pojmovanja, znanja, vrednotenja o geografskem okolju kot viru surovin in energije ter nezamenljivi, zdravi areni človekovega bivanja sedanjih generacij, bo potrebno razširiti na obravnavo geografskega okolja kot arene bivanja vseh vrst in prihodnjih generacij. Varstvo geografskega okolja je potrebno pojmovati ne le kot pasivno zaščito okolja, temveč tudi kot njegovo preudarno aktivno urejanje in sonaravno (naravnim zakonitostim prilagojeno) gospodarjenje z njegovimi sestavinami. Označuje postopen premik k pogledu na svet kot varen, kakovosten in trajen dom vseh vrst ter bodočih generacij.

V geografiji sonaravni razvoj (napredek) pomeni usmeritev prostorskega, gospodarskega in regionalnega razvoja v okviru (različnih) zmogljivosti (omejitev) geografskega okolja, pokrajine. Obsega razvoj poselitve, gospodarstva, infrastrukture in pokrajinske rabe hkrati z varstvom (bivalnega) okolja, varstvo naravnih (okoljskih) virov, varstvo narave oziroma ohranjanje pokrajinske, ekosistemske, vrstne pestrosti. Torej označuje načrtovanje okoljevarstveno in naravovarstveno trajno sprejemljive stopnje in obsega antropogene preobrazbe geografskega okolja. 
Tudi geografija kot znanstvena veda o pokrajini, geografskem okolju ima veliko priložnost, da torej strokovno argumentirano in samozavestno ponudi različne sonaravne poti in vzorce prostorske organizacije človekovih dejavnosti pokrajinsko mozaičnega planeta in Slovenije. Koncept trajnostnosti je tako priložnost kot tudi test enotnosti pogosto razdrobljene geografije. Potrjuje, da ostajajo interakcije med okoljem in družbo ključni povezujoči koncept geografije kot znanstvenoraziskovalne discipline. Zaradi znanstvenoraziskovalnih prednosti geografije pa je umestno okoljski trajnosti $z$ vidika geografskih sonaravnih in razvojno zasnovanih poudarkov (prostorski in regionalni razvoj) nameniti večjo pozornost, v smeri novih, bolje rečeno, prenovljenih raziskovalnih polj in učnih predmetov - geografije sonaravnega razvoja/napredka in geografije okoljskih virov.

Okoljski pritiski na okolje so torej v številnih območjih sveta presegli zmogljivosti okolja, okoljska globalizacija je prinesla izčrpavanje naravnih virov, podnebne spremembe in zmanjševanje pokrajinske in biotske raznovrstnosti. Tudi v Sloveniji in njenih regijah prevladujejo netrajnostne oblike poselitve, infrastrukture in pokrajinske rabe, ki jih med drugim lahko celostno raziskuje geografija. Vsako izčrpavanje okoljskih virov, vsaka oblika degradacije okolja (onesnaževanje, pozidava itd.) zmanjšuje njegovo nosilnost, zmogljivost opravljanja storitev okolja (pokrajinskih storitev, uslug, vključno z zmanjšanimi samočistilnimi sposobnostmi in antropogeno pospešenimi naravnimi nesrečami), ki naj bi jih preučevala tudi geografija. Okoljske vire lahko definiramo kot tiste dele narave, ki lahko človeku zagotavljajo dobrine (surovine, energija), prostor za dejavnosti in storitve, vključno z ekosistemskimi, kot so zmogljivost samočiščenja, proizvodnja kisika, možnosti za rekreacijo, vrednotenje pejsažne lepote ali možnost odlaganja odpadkov. Za razliko od naravnih virov, kjer je v ospredju vrednotenje njihovega ekonomskega pomena, vključujejo okoljski viri tudi tržno neovrednotene ekosistemske storitve, zato je vrednotenje okoljskih virov (virov okolja) širše, razvojno (ekonomsko-tehnološko) in varovalno (ekosistemsko) uravnoteženo.

Slovenska geografija lahko ob sodelovanju z drugimi vedami ponudi realno, regionalno specifično alternativo sedanjemu načinu enostranske rabe virov okolja, prevladujoči obstoječi materialni in prostorski organizaciji družbe na slovenskem podeželju (zlasti na obsežnih varovanih območjih) in mestih, ki naj bo zasnovana tudi na upoštevanju pomena nosilne zmogljivosti okoljskih virov, sestavin okolja. Regionalnogeografsko je potrebno osvetliti že obstoječe, tudi tradicionalne primere trajnostnega načina organizacije poselitve in dejavnosti, ki omogočajo večjo stopnjo prehranske, energijske in drugih oblik državne in regionalne samoskrbe, ki so bile globalizacijsko neupravičeno povožene, pa tudi primerno bivalno okolje prihodnjim generacijam in hkrati ohranjanje pokrajinske (in biotske) raznovrstnosti Slovenije in njenih regij. Koncepta okoljskega prostora in ekoloških odtisov (oziroma sledi) sta lahko pomembni metodologiji določanja načina rabe virov in zgornjih mej okoljskih pritiskov tudi na regionalni ravni.

Geografija se lahko še bolj samozavestno vključi v oblikovanje potrebnih razvojnih strategij, projektov in ukrepov, ki bi Sloveniji omogočili trajnostno, sonaravno organizacijo poselitve in materialnega življenja ob upoštevanju svojstvenih geografskih razmer v regijah, pokrajinah. Postopno družbeno prepoznavanje nujnosti večplastnega, kompleksnega vrednotenja regionalnih razvojno-varovalnih potencialov in širšega pojmovanja blagostanja, kakovosti življenja, ponovnega pomena različnih oblik samoskrbe pomeni za tradicionalno mostiščno 
vlogo geografije enkratno priložnost ne le utrjevanja, temveč povečanja njenega družbenega pomena.

Načrtovanje in udejanjanje organizacije materialne dejavnosti v okviru lokalnih, regionalnih in planetarnih zmogljivosti geografskega okolja, optimalna raba virov okolja in ohranjanje pokrajinske raznovrstnosti ter sanacija degradiranega geografskega okolja so nosilni vsebinski in seveda raziskovalni stebri vsebine geografije sonaravnega okolja in okoljskih virov Oddelka.

\section{ZAKLJUČEK}

Tudi na Oddelku je geografija na področju degradacije in varstva geografskega okolja $\mathrm{v}$ zadnjih petdesetih letih prehodila izvijugano, spiralno zasnovano znanstvenoraziskovalno pot med specializacijo in zelo posplošeno kompleksnostjo. Po mnenju pisca se je praviloma dokaj uspešno uprla obema vabljivima možnostima enostranskega raziskovanja in prispevala svoj delež k razvoju in ugledu slovenske geografije ter argumentiranju, opozarjanju in delno tudi k reševanju okoljskih problemov. Verjetno pa je njen najbolj pomemben raziskovalni in uporabni prispevek prav na področju prepotrebne reintegracije geografije in aplikativno zasnovanih regionalnogeografskih raziskav vzrokov in ključnih pokrajinskih posledic pretežno sinergijskega delovanja degradacijskih antropogenih procesov. Uspešnost odgovorov na prihodnje znanstvenoraziskovalne, vzgojno-izobraževalne in širše uporabne izzive pa je $\mathrm{v}$ veliki meri odvisen ne le od specializiranega okoljskega raziskovanja nekaterih članov Oddelka, temveč od prihodnjega obsega, stopnje in (ne)uspešnosti 'ekologizacije' Oddelka in celotne slovenske geografije. Slovenska geografija in Oddelek si seveda ne moreta 'privoščiti' zgolj poglobljenega okoljskega raziskovanja na račun zanemarjanja ostalih, enako pomembnih geografskih vsebinskih polj in usmeritev, pa tudi ne naivno nasesti vabljivi iluziji, da imamo geografi zaradi tradicionalnih in vkoreninjenih okoljskih geografskih genov trajne primerjalne prednosti pred drugimi znanostmi o prostoru, okolju, razmerju med človekom in okoljem, naravo. V kolikor regionalno kompleksnih okoljskih, trajnostno sonaravnih raziskav ne bo opravljala slovenska geografija, jih bodo pač bolj ali manj uspešno opravile druge sorodne znanosti, kar se deloma že dogaja.

Okoljska geografija Oddelka (in izven njega) mora biti torej sposobna na osnovi kompleksne pokrajinske analize postaviti korektno okoljsko diagnozo (ekološka geografija z geografsko zasnovano humano ekologijo, geografija okoljskih virov) geografskih območij Slovenije, a tudi predvideti posledice doseganja blagostanja v različnih lokalnih razmerah ali prostorskih razmestitvah (okolje), torej prepričljivo postaviti regionalno okoljsko prognozo (geografija sonaravnega razvoja).

\section{Viri in literatura}

Bat, M., Lovrenčak, F., Plut, D., Radinja, D., Špes, M. 1985: Za ekološko svetlejši jutri. Zveza organizacij za tehnično kulturo Slovenije. Ljubljana.

Berdavs, J., Gosar, A., Kerma, S., Kovačič, G., Staut, M. 2006: Prostorska izhodišča za načrtovanje trajnostnega razvoja na območju Koprskega primorja (izhodišča). Živeti s pri- 
staniščem. Trajnostni razvoj pristanišča Koper in Južnoprimorske regije. Univerza na Primorskem, str. 17-43. Koper.

Bohinec, V. 1938: Varstvo narave na Poljskem. Proteus 5, 2, str. 29-31. Ljubljana.

Brečko Grubar, V., Hočevar, M., Lampič, B., Natek, K., Plut, D., Smrekar, A., Šebenik, I., Špes, M., Vovk Korže A. 1996: Ranljivost okolja. Spodnje Podravje s Prlekijo. Možnosti regionalnega in prostorskega razvoja, Zveza geografskih društev Slovenije, str. 53-109. Ljubljana.

Brečko Grubar, V. 1996: Podtalnica Ljubljanskega polja - najpomembnejši vodni vir za oskrbo Ljubljane. Geografski vestnik 68, str. 203-212. Ljubljana.

Brečko Grubar V. 1998a: Pokrajinska občutljivost območij podtalnic z vidika kmetijstva. Zbornik posveta Kmetijstvo in okolje. Kmetijski inštitut Slovenije, str. 49-55. Ljubljana.

Brečko Grubar, V. 1998b: Pokrajinske značilnosti območij virov pitne vode v jugovzhodni Ljubljanski kotlini. Geografski vestnik 70, str. 27-43. Ljubljana.

Brečko Grubar, V. 1999: Landscape vulnerability of Ljubljana's most important water source. Geografski zbornik 39, str. 51-92. Ljubljana.

Brečko Grubar, V. 2007: Vloga naravnogeografskih značilnosti pri sonaravnem upravljanju z vodnimi viri v porečju Kamniške Bistrice. Dela 28, str. 305-322. Ljubljana.

Brečko Grubar, V. 2009: Hidrogeografske značilnosti porečja kot osnova za celostno upravljanje s porečjem Mure. Pomurje. Geografski pogledi na pokrajino ob Muri. Zveza geografov Slovenije, Društvo geografov Pomurja, str. 84-92. Murska Sobota.

Cigale, D. 2007: Vplivi turizma v slovenskem alpskem svetu na vode. Dela 28, str. 255-271. Ljubljana.

Cigale, D., Lampič, B. 2003: Noise as quality factor of urban environment. Journal of Balkan ecology 6, 4, str. 409-416. Sofija.

Cigale, D., Lampič, B., Ogrin, M., Plut, D., Rebernik, D., Špes, M., Vintar Mally, K., Cetkovský, S., Kallabová, E., Mikulík, O., Vaishar, A., Zapletalová, J. 2006: Sustainable development of small towns. A Slovenian-Moravian comparative methodological approach. Moravian geographical reports 14, 1, str. 17-28. Brno.

Černe, A. 1977: Proučitev degradacije okolja v Velenjski kotlini s pomočjo faktorske analize. Geografski vestnik 49, str. 65-71. Ljubljana.

Černe, A. 1978: Degradacija okolja v Velenjski kotlini. Naše okolje 5-6/78, str. 200-201. Ljubljana.

Domitrovič Uranjek, D. 1978: Vpliv urbanizacije in deagrarizacije na oblikovanje omrežja centralnih naselij in kakovosti življenjskega okolja. Naše okolje 5-6/78, str. 191-192. Ljubljana.

Gams, I. 1968: Kaj bo z Rakom? Proteus 30, 6, str. 163-165. Ljubljana.

Gams, I. 1969: Varstvo jamskih kapnikov v luči novih raziskovanj. Varstvo narave 6, str. 15-23. Ljubljana.

Gams, I. 1972: Ekosistem in vprašanje ogroženosti zemeljske atmosfere. Geografski obzornik 19, 2, str. 6-11. Ljubljana.

Gams, I. 1974: Kras. Zgodovinski, naravoslovni in geografski oris. Slovenska matica. Ljubljana.

Gams, I. 1975: Problemi geografskega raziskovanja ekotopov in pokrajinske ekologije v Sloveniji. Geografski vestnik 57, str. 133-140. Ljubljana. 
Gams, I. 1986: Osnove pokrajinske ekologije (univerzitetni učbenik). Oddelek za geografijo Filozofske fakultete. Ljubljana.

Gams, I. 1994: Changes of the Triglav glacier in the 1955-94 period in the light of climatic indicators. Geografski zbornik 34, str. 81-117. Ljubljana.

Gams, I. 1998: O napovedani podnebni spremembi in njenem vplivu na naravne nesreče v Sloveniji. Ujma 12, str. 79-82. Ljubljana.

Gams, I., Lovrenčak, F., Plut, D. 1978: Soča, Breginj in Kamno v pokrajinsko-ekološki primerjavi. Zgornje Posočje. Zbornik 10. zborovanja slovenskih geografov. Geografsko društvo Slovenije, str. 335-347. Ljubljana.

Geografski terminološki slovar. Založba ZRC. Ljubljana 2005.

Gosar, A. 1987: Učinki počitniških bivališč na preobrazbo slovenske kulturne pokrajine. Geographica Slovenica 18, str. 183-204. Ljubljana.

Gosar, A. 1993: International tourism and its impact on the Slovenian society and landscape. GeoJournal 30, 3, str. 339-348. Dordrecht.

Gosar, A., Jurinčič, I. 2003: Sustainable tourism in the Alpen-Adria region: reality and goals. Dela 19, str. 141-151. Ljubljana.

Herbert, D. T., Matthews J.A. 2004: Geography: roots and continuities. V: Unifying geography. Common heritage, shared future. Routledge, str. 3-20. London, New York.

Ilešič, S. 1959: Beležke o načelni problematiki geografije. Geografski vestnik 31, str. 149157. Ljubljana.

Ilešič, S. 1962: O pojmu resničnega geografskega okolja. Geografski obzornik 9, 3-4, str. 23-25. Ljubljana.

Ilešič, S. 1964: Preostanki preteklosti v pokrajini kot element resničnega geografskega okolja. Geografski vestnik 36, str. 3-12. Ljubljana.

Ilešič, S. 1972: O geografskih aspektih varstva okolja. Geografski obzornik 19, 2, str. 2-5. Ljubljana.

Ilešič, S. 1973: Široko in aktivno "varstvo" življenjskega okolja: ne gre za pasivno, rezervatorsko varovanje prvotne narave, ker ljudje ne morejo živeti, marveč za preudarno negovanje, urejanje in preurejanje življenjskega okolja človeške družbe. Naši razgledi 22, 2 (26. 1. 1973), str. 25. Ljubljana.

Ilešič, S. 1979: Pogledi na geografijo. Partizanska knjiga. Ljubljana.

Jeršič, M. 1976: Zasnove uporabe prostora - rekreacija. Zavod za družbeno planiranje. Ljubljana.

Jeršič, M. 1989: Turizem kot možnost in nevarnost za ohranitev naravne in kulturne pokrajine. V: Slovenija '88. Slovenska akademija znanosti in umetnosti, str. 338-341. Ljubljana.

Jeršič, M. 1999: Slovenske Alpe - kulturna pokrajina - naravni park - športna arena? Dela 13, str. 47-61. Ljubljana.

Jeršič, M. 2001: Okoljski vidiki planiranja rekreacije. V: Turizem in okolje. Zbirka Usklajeno in sonaravno 6. Svet za varstvo okolja Republike Slovenije, str. 41-49. Ljubljana.

Klemenčič, M. M., Lampič, B., Potočnik Slavič, I. 2008: Življenjska (ne)moč obrobnih podeželskih območij v Sloveniji. Zbirka GeograFF 3. Znanstvena založba Filozofske fakultete, Oddelek za geografijo. Ljubljana. 
Klemenčič, V. 1972: Izkoriščanje zemlje. V: Zelena knjiga o ogroženosti okolja v Sloveniji. Prirodoslovno društvo Slovenije, Zavod za spomeniško varstvo SR Slovenije, str. 15-17. Ljubljana.

Kokole, V. 1974: Novi pogledi na proučevanje okolja. Geografski vestnik 45, str. 121-129. Ljubljana.

Kunaver, J. 1981: Geografski pomen Triglavskega narodnega parka. Gorenjska. Referati in gradivo na 12. zborovanju slovenskih geografov v Kranju in na Bledu od 15. do 17. oktobra 1981. Geografsko društvo Slovenije, str. 138-146. Ljubljana.

Kunaver, J. 1989: Znanje in izobraževanje, Varstvo okolja in pouk geografije. V: Slovenija '88. Slovenska akademija znanosti in umetnosti, str. 191-194. Ljubljana.

Kunaver, J. 1996: Environmental learning in geographical education on the example of Slovene Karst. V: Innovation in geographical education. 28th Congress of the International Geographical Union, The Hague, The Netherlands, August 4-10 1996, str. 129-135. Amsterdam.

Kunaver, J. 1997: Problem okoljskih vsebin pri pouku geografije doma in po svetu, Geografija v šoli 6, 1, str. 28-34. Ljubljana.

Kunaver, J. 2007: Geomorfološke vsebine in njihova zastopanost v razlagi pokrajinskih značilnosti Triglavskega narodnega parka v primerjalni luči. Dela 28, str. 133-146. Ljubljana.

Kušar, S. 2001: Metodologija ocenjevanja pokrajinskega vpliva neurejenih odlagališč odpadkov na kakovost podtalnice v prodnih sedimentih. Geografski vestnik 73, str. 61-71. Ljubljana.

Lah, A. 1972: Proučevanje, urejanje in varstvo okolja. Geografski obzornik 19, 4, str. 1-19. Ljubljana.

Lah, A. 1978: Ekonomski (ekonometrični) in humanistični vidik okolja. Naše okolje 5-6/78, str. 180-185. Ljubljana.

Lah, A. 2002: Okoljski pojavi in pojmi. Zbirka Usklajeno in sonaravno 8. Svet za varstvo okolja Republike Slovenije. Ljubljana.

Lampič B. 2000a: Izbrani razvojni in okoljevarstveni problemi slovenskega podeželja z vidika sonaravnega razvoja. Geographica Slovenica 33, 1, str. 157-202. Ljubljana.

Lampič, B. 2000b: Agricultural pollution of the environment in Slovenia from the aspect of energy and nitrate consumptions. Moravian geographical reports 8, 2, str. 2-13. Brno.

Lampič, B. 2007a: Okoljska in razvojna vloga kmetijstva v Mestni občini Ljubljana. Dela 28, str. 359-379. Ljubljana.

Lampič, B. 2007b: Demographic vitality of population as an important development potential of protected areas. V: Sustainable environmental research, str. 121-124. Olomouc.

Lampič, B. 2008: Kmetijstvo v Mestni občini Ljubljana - relikt ali razvojni potencial. Zbirka GeograFF 2. Znanstvena založba Filozofske fakultete, Oddelek za geografijo. Ljubljana.

Lampič, B. 2009: Ljubljana - agriculture in the municipality of Ljubljana. Relic or development potential? New challenges for sustainable rural development in the 21 st century. Sustainable development in Slovenian regions / The 17th Annual colloquium of the IGU Commission on the Sustainability of Rural Systems, Maribor, 13th-18th July 2009. Department of Geography, Faculty of Arts, University of Maribor, str. 126-130. Maribor. 
Lampič, B., Smrekar A. 1998: Vzpostavitev GIS-a naravne dediščine na primeru Radenskega polja. V: Geografski informacijski sistemi v Sloveniji 1997-1998. Zbornik referatov simpozija, Ljubljana, 29. september 1998. ZRC SAZU, str. 159-166. Ljubljana.

Lampič, B., Mrak, I. 2007a: Nature conservation in Slovenia. V: Sustainable environmental research, str. 26-34. Olomouc.

Lampič, B., Mrak, I. 2007b. The geographic characteristics and significance of Triglav National Park as a principal protected area in Slovenia. V: Sustainable environmental research, str. 99-106. Olomouc.

Lampič, B., Špes, M., Vaishar, A., Plut, D., Vintar Mally, K., Rebernik, D., Cigale, D., Zapletalová, A., Kallabová, E., Cetkovský, S. 2007: Sustainable development of small towns (uredili B. Lampič in M. Špes). Oddelek za geografijo, Filozofska fakulteta; Ústav Geoniky Akademie Věd České Republiky. Ljubljana, Brno.

Lampič, B., Potočnik Slavič, I. 2007: Demographic vitality and human resources as important factors for rural areas development. Glasnik Srpskog geografskog društva 87, 2, str. 103114. Beograd.

Lampič, B., Mrak, I. 2008: Vrednote, vrednosti in razvojni potenciali območij varovanja. Dela 29, str. 145-159. Ljubljana.

Lovrenčak, F. 1997: Geoecosystems in the Planica valley (the Julian Alps, Slovenia). Abstracts of the European conference on environmental and societal change in mountain regions, 18-20 December 1997. Oxford.

Lovrenčak, F. 2003: Pokrajinskoekološke enote v Planici. Dela 20, str. 75-80. Ljubljana.

Marsh, W. M., Grossa, J. 2002: Environmental geography. J. Wiley \& Sons. New York.

Mihevc, P. 1972: Ob pojmu »človekovo okolje«. Geografski obzornik 19, 2, str. 38-41. Ljubljana.

Mrak, I. 2007a: Onesnaženost ledenika Baltoro kot posledica turistične dejavnosti. Dela 28, str. 381-396. Ljubljana.

Mrak, I. 2007b: Sustainable tourism development in mountain areas. V: Sustainable environmental research, str. 125-128. Olomouc.

Mrak, I. 2008: Small size protected areas - development potentials of Slovenia. Hrvatski geografski glasnik 70, 1, str. 5-23. Zagreb.

Natek, K. 1996: Ogroženost in regeneracijske sposobnosti površja severovzhodne Slovenije na osnovi regeneracije površja v Halozah po katastrofalnem neurju julija 1989. Spodnje Podravje s Prlekijo. Možnosti regionalnega in prostorskega razvoja. Zveza geografskih društev Slovenije, str. 141-151. Ljubljana.

Natek, K. 1999: Možnosti nadaljnjega sonaravnega razvoja ob treh sosednjih južnoalpskih rekah: Piavi, Tilmentu in Soči. Dela, 13, str. 201-214. Ljubljana.

Natek, K. 2007: Geografske dimenzije naravnih nesreč in varstva pred njimi. Dela 28, str. 147-164. Ljubljana.

Ogrin, D. 2003: Spreminjanje temperature zraka in padavin po letnih časih v Ljubljani in Trstu v obdobju 1851-2002. Dela 20, str. 115-132. Ljubljana.

Ogrin, D. 2009: Slabitev celinskih podnebnih značilnosti v zadnjih desetletjih. Pomurje. Geografski pogledi na pokrajino ob Muri. Zveza geografov Slovenije, Društvo geografov Pomurja, str. 66-78. Murska Sobota. 
Ogrin, M. 2007: Air pollution due to road traffic in Ljubljana. Dela 27, str. 199-214. Ljubljana.

Ogrin, M. 2008: Prometno onesnaževanje ozračja z dušikovim dioksidom v Ljubljani. Zbirka GeograFF 1, Znanstvena založba Filozofske fakultete, Oddelek za geografijo. Ljubljana.

Orožen Adamič, M. 1970: Kako naj vrednotimo pokrajino? Proteus 33, 4, str. 152-156. Ljubljana.

Orožen Adamič, M., Pleskovič, B. 1975: Problemi okolja in odlaganje trdih odpadkov v Ljubljani. Geografski vestnik 47, str. 121-132. Ljubljana.

Orožen Adamič, M. 1978: Oris problematike odpadkov v Ljubljani. Naše okolje 5-6/78, str. 193-194. Ljubljana.

Plut, D. 1977: Valorizacija kopališč in onesnaževanja okolja v Koprskem Primorju. Naše okolje 5/77, str. 250-254. Ljubljana.

Plut, D. 1978: Vrednotenje posegov družbe v geografsko okolje in bodoči prostorski razvoj Koprskega Primorja. Naše okolje 5-6/78, str. 202-205. Ljubljana.

Plut, D. 1981: Pokrajinska ekologija Bele krajine. Geographica Slovenica 12, str. 141-166. Ljubljana.

Plut, D. 1987: Slovenija - zelena dežela ali pustinja? Zbirka Krt 43. Ljubljana.

Plut, D. 1988: Belokranjske vode. Dolenjski muzej. Novo mesto.

Plut, D. 1991: Entropijska zanka. Didakta. Radovljica.

Plut, D. 1995: Sustainable regional policy of Slovenia - a state in transition. Regional contact 9, 10, str. 92-97. København.

Plut, D. 1998: Varstvo geografskega okolja (univerzitetni učbenik). Oddelek za geografijo Filozofske fakultete. Ljubljana.

Plut, D. 2004a: Zeleni planet? Prebivalstvo, energija in okolje v 21. stoletju. Didakta. Radovljica.

Plut, D. 2004b: Geografske metode proučevanja degradacije okolja. Oddelek za geografijo Filozofske fakultete. Ljubljana.

Plut, D. 2004c: Tipologija in okoljevarstvene usmeritve v večjih pokrajinsko degradiranih območjih Slovenije. V: Prostorske znanosti za 21. stoletje. Fakulteta za gradbeništvo in geodezijo, str. 135-146. Ljubljana.

Plut, D. 2005: Teoretična in vsebinska zasnova trajnostno sonaravnega napredka. Dela 23, str. 59-114. Ljubljana.

Plut, D. 2006: Mesta in sonaravni razvoj. Razprave Filozofske fakultete. Ljubljana.

Plut, D. 2007: Ljubljana in izzivi sonaravnega razvoja. Oddelek za geografijo Filozofske fakultete. Ljubljana.

Plut, D., Špes, M., Brečko Grubar V. 2002: Slovenia. Country studies - northern group. Environmental problems of East Central Europe. Routledge studies of societies in transition, str. 228-247. London, New York.

Plut, D., Ivanovič, M., Dular, J., Natek, K., Stepišnik, U., Ogrin, D., Brečko Grubar, V., Repe, B., Lovrenčak, F., Ogrin, M., Mrak, I. 2008: Bela krajina in Krajinski park Lahinja. Znanstvena založba Filozofske fakultete, Oddelek za geografijo. Ljubljana.

Radinja, D. 1965: Projektirana HE Trnovo v Soški dolini. Geografski obzornik 12, 4, str. 114-119. Ljubljana. 
Radinja, D. 1966. Geografska problematika hidroenergetskega izkoriščanja Soške doline. Geografski obzornik 13, 3-4, str. 98-104. Ljubljana.

Radinja, D. 1967: Načrti o zaščiti kraške pokrajine na Tržaškem. Geografski obzornik 14, 4, str. 117-121. Ljubljana.

Radinja, D. 1972: Onesnaženost človekovega okolja v luči geografske terminologije. Geografski obzornik 19, 1, str. 35-39. Ljubljana.

Radinja, D. 1974: Geografija in varstvo človekovega okolja. Geografski vestnik 46, str. 110120. Ljubljana.

Radinja, D. 1977: Onesnaževanje pokrajin in pokrajinske sfere z nafto. Geografski obzornik 24, 1-2, str. 30-40. Ljubljana.

Radinja, D. 1978a: Pokrajinske značilnosti industrializacijske onesnaženosti v Sloveniji. Naše okolje 5-6/78, str. 186-190. Ljubljana.

Radinja, D. 1978b: Največja umetna jezera na svetu - svojevrstna preobrazba pokrajinske sfere. Geografski obzornik 25, 3-4, str. 18-36. Ljubljana.

Radinja, D. 1979: Onesnaženost slovenskih rek in njene pokrajinske značilnosti. Geografski vestnik 51, str. 3-18. Ljubljana.

Radinja, D. 1980a: Onesnaževanje in varstvo okolja na primeru izbranega industrijskega ali kmetijskega obrata (zadruge): navodila za raziskavo. Geografski obzornik 27, 3-4, str. 44-47. Ljubljana.

Radinja D. 1980b: Značilnosti vodne oskrbe v naftnih pokrajinah puščavskega sveta, razsoljevanje morske vode v današnjem svetu. Geografski obzornik 27, 3-4, str. 9-16. Ljubljana.

Radinja, D. 1983: Degradacija okolja v Radovljiški kotlini. Geographica Slovenica 14, str. 64-66. Ljubljana.

Radinja, D. 1984: Oskrba s pitno vodo v novomeški občini. Dolenjska in Bela krajina. Geografsko društvo Slovenije, str. 111-128. Ljubljana.

Radinja, D. 1987: Varstvo okolja in geografija. Notranjska. Zbornik 14. zborovanja slovenskih geografov. Zveza geografskih društev Slovenije, str. 19-22. Ljubljana.

Radinja, D., 1988a: O tehnogenem kroženju žvepla v pokrajinskem okolju SR Slovenije in njegovi bilanci. Geografski vestnik 60, str. 3-19. Ljubljana.

Radinja, D. 1988b: Širša degradacijska problematika Blejskega jezera z vidika njegove pokrajinske strukture. Geographica Slovenica 19, str. 99-134. Ljubljana.

Radinja, D. 1996: Obremenjevanje pokrajinskega okolja v Sloveniji zaradi energijske intenzivnosti »družbenega« kmetijstva. Geografski vestnik 68, str. 103-121. Ljubljana.

Radinja, D. 1997: Vprašanja o agrarnem preobremenjevanju pokrajinskega okolja v Sloveniji, Geografija v šoli VI/2-3, str. 105-109. Ljubljana.

Radinja, D. 1999: Problematika sonaravnega razvoja v slovenskem alpskem svetu (na primeru Rateške pokrajine). Dela 13, str. 115-133. Ljubljana.

Ravbar, M. 1975: Preobrazba obmestij slovenskih mest s črno gradnjo. Geografski vestnik 47, str. 149-160. Ljubljana.

Ravbar, M. 1976: Naravovarstvena območja v Kamniško-Savinjskih Alpah. Planinski vestnik 76, 4, str. 180-182. Ljubljana.

Ravbar, M. 1977: Naravna dediščina Slovenije: prvina človekovega okolja. Geografski obzornik 24, 1-2, str. 1-5. Ljubljana. 
Ravbar, M. 1978: Varstvo pokrajine v luči preobrazbe naselij s črno gradnjo. Varstvo narave 11, str. 17-34. Ljubljana.

Ravbar, M., Orožen Adamič, M. 1978: Varstvo narave ter problemi okolja ob načrtih za hidroelektrarne v Zgornjem Posočju. Zgornje Posočje. Zbornik 10. zborovanja slovenskih geografov. Geografsko društvo Slovenije, str. 231-247. Ljubljana.

Ravbar, M., Plut, D. 1999: Prispevek k proučevanju regionalno-geografskih razsežnosti oblikovanja mestnih regij v Sloveniji v pogojih globalizacije in trajnostno sonaravnega razvoja. Dela 14, str. 99-114. Ljubljana.

Rebernik, D. 2007: Trajnostni prostorski razvoj in novejši procesi v prostorskem razvoju Ljubljane. Dela 27, str. 17-38. Ljubljana.

Repe, B. 2002: Soil degradation threat to Slovenia's landscapes. Geografski zbornik 42, str. 99-121. Ljubljana.

Repe, B. 2009: Trajne spremembe rabe tal in degradacija prsti. Pomurje. Geografski pogledi na pokrajino ob Muri. Zveza geografov Slovenije, Društvo geografov Pomurja, str. 104 116. Murska Sobota.

Resnik Planinc, T. 2006: Vrednote prostora kot integralni del izobraževanja. Geografski vestnik 78, 2, str. 9-24. Ljubljana.

Resnik Planinc, T. 2008a: Geographical education and values of space: a comparative assessment from five European countries. International research in geographical and environmental education 17, 1, str. 56-73. Bundoora.

Resnik Planinc, T. 2008b: Vrednote prostora v procesu geografskega izobraževanja. Dela 29, str. 21-35. Ljubljana.

Špes, M. 1977: O problemih življenjskega okolja v Celju. Geografski vestnik 49, str. 73-80. Ljubljana.

Špes, M. 1978: Problemi življenjskega okolja v Celjski kotlini. Naše okolje 5-6/78, str. 195199. Ljubljana.

Špes, M. 1979: Degradacija okolja na primeru Celja. Geographica Slovenica 9, str. 27-40. Ljubljana.

Špes, M. 1984: Sozialgeographische Untersuchungen in umweltbelasteten Stadtteilen ausgewählter slowenischer Städte. Münchener Studien zur Sozial- und Wirtschaftsgeographie 27, str. 41-48. Regensburg.

Špes, M. 1987: Pokrajinski učinki onesnaževanja okolja v kotlinah in ozkih dolinah. Zbornik XII kongresa geografa Jugoslavije. Savez geografskih društava Jugoslavije, Geografsko društvo Vojvodine, str. 477-482. Novi Sad.

Špes, M. 1990: Industrijski obrati in njihov vpliv na okolje Koprskega Primorja. Primorje. Zbornik 15. zborovanja slovenskih geografov. Zveza geografskih društev Slovenije, str. 195-207. Ljubljana.

Špes, M. 1996: Zustand und Entwicklung der Umwelt in Slowenien - ein Überblick. Österreichische Osthefte 38, 1, str. 69-78. Wien.

Špes, M. 1998: Degradacija okolja kot dejavnik diferenciacije urbane pokrajine. Geographica Slovenica 30, 199 str. Ljubljana.

Špes, M., 2000: Geografske značilnosti pokrajinsko ranljivih območij v Sloveniji. Geographica Slovenica 33, 1, str. 9-46. Ljubljana. 
Špes, M. 2007a: Pokrajinska občutljivost urbanih ekosistemov v Sloveniji. IB revija 39, 4, str. 26-35. Ljubljana.

Špes, M. 2007b: Pomen vzdrževanja dinamičnega ravnovesja za sonaravni razvoj. Dela 28, str. 273-285. Ljubljana.

Špes, M. 2008: Slowenien auf dem Weg in die Nachhaltigkeit. Slowenien. Transformationen und kleinräumige Vielfalt. Natur - Raum - Gesellschaft 5, str. 108-132. Frankfurt am Main.

Špes, M. 2009: Mesto kot ekosistem. Dela 31, str. 5-20. Ljubljana.

Špes, M., Plut, D. 1982: Socialnogeografsko proučevanje degradiranih območij v nekaterih slovenskih mestih. Geographica Slovenica 13, str. 28-39. Ljubljana.

Špes, M., Lampič, B., Smrekar, A. 1995: Case study: Ljubljana: the cultural and economic conditions of decison-making for the sustainable city. Moravian geographical reports 3, 1-2, str. 66-85. Brno.

Špes, M., Smrekar, A., Lampič, B. 2000: Kvaliteta bivalnega okolja v Ljubljani. Ljubljana: geografija mesta. Ljubljansko geografsko društvo, Založba ZRC, ZRC SAZU, str. 163174. Ljubljana.

Špes, M., Smrekar, A., Lampič, B. 2001: Influence of physical and social factors on the quality of urban environment in Ljubljana. Moravian geographical reports 9, 1, str. 11-21. Brno.

Špes, M., Cigale, D., Lampič, B. 2002a: Izstopajoči okoljski problemi v Ljubljani. V: Geografija Ljubljane. Oddelek za geografijo Filozofske fakultete, str. 53-83. Ljubljana.

Špes, M., Cigale, D., Lampič, B., Natek, K., Plut, D., Smrekar, A. 2002b: Študija ranljivosti okolja (metodologija in aplikacija). Geographica Slovenica 35, 1-2, 150 str. Ljubljana.

Vintar Mally, K. 2002: Vrednotenje regionalnega razvoja Spodnjega Posavja z vidika sonaravnosti. Geografski vestnik 74, 2, str. 21-31. Ljubljana.

Vintar Mally, K. 2003a: Udejanjanje sonaravnega razvoja - Slovenija na pragu EU. Geografija v šoli 12, 3, str. 13-20. Ljubljana.

Vintar Mally, K. 2003b: Sustainable regional development - a new challenge of Slovenian regional policy. V: Regional geography and its application: Papers of the 5th Moravian geographical conference CONGEO’03, str. 186-190. Brno.

Vintar Mally, K. 2005: A challenge of sustainable development in Slovenia and South Eastern European countries. V: South Eastern European countries on their way to Europe - geographical aspects. Faculty of Science, Department of Geography, str. 1-10. Zagreb.

Vintar Mally, K. 2006: Prednosti in omejitve uporabe kazalcev sonaravnega razvoja. Dela 26, str. 43-59. Ljubljana.

Vintar Mally, K. 2007a: Linking socio-economic development and environmental pressures. Dela 27, str. 149-162. Ljubljana.

Vintar Mally, K. 2007b: Trajnostni izzivi Evrope v 21. stoletju. Dela 28. str. 239-253. Ljubljana.

Vintar Mally, K. 2009: (Ne)sonaravnost razvoja slovenskih regij. Razvojni izzivi Slovenije, str. 263-270. Ljubljana.

Vovk Korže, A. 1997: Spreminjanje pokrajine zaradi posegov človeka. Geografija v šoli 6, 2-3, str. 100-104. Ljubljana.

Vovk Korže, A. 2002: Naravni potenciali regij in njihova raba. Dela 18, str. 75-91. Ljubljana. 
Zelena knjiga o ogroženosti okolja v Sloveniji. Prirodoslovno društvo Slovenije, Zavod za spomeniško varstvo SR Slovenije. Ljubljana 1972.

\title{
AN OUTLINE OF INVESTIGATION IN THE FIELD OF ENVIRONMENTAL GEOGRAPHY ON THE OCCASION OF THE $90^{\text {th }}$ ANNIVERSARY OF THE DEPARTMENT OF GEOGRAPHY AT THE FACULTY OF ARTS IN LJUBLJANA
}

\begin{abstract}
Summary
Professionally, thorough interest and investigation into the problems of protection of environment and nature in Slovenia began with the efforts to establish the Triglav National Park already after the First World War. After the period of underlining merely the positive results of the industrialization and urbanization immediately after the Second World War, in the 1960s Slovenian geographers began to point out also the negative environmental impacts of the accelerated economic development of the 1960s and 1970s.

In the 1970s the development of environmental geography at the Department of Geography at the Faculty of Arts in Ljubljana (hereinafter: Department) and outside it was initially well marked with technical-methodological treatises on the subject and the contents of geographical investigation into the environment, its pollution (broader degradation) and protection. At the beginning of the 1970s, particularly two geographers, Svetozar Ilešič and Darko Radinja, devised theoretically, methodologically and terminologically the necessary frameworks for both the geographical definition of human-nature relationship and the (more-than-)necessary geographical investigations into ever more acute environmental problems in certain Slovenian landscapes. In the second half of the 1970s, the associates of the Department already published the results of their first concrete geographical investigations into the landscape-degraded areas in Slovenia.

In the first period of environmental geography at the Department (and also in Slovenian geography as a whole), the central attention was focused on the envisaging of a firm theoreticalmethodological basis for concrete investigations and on the first attempts at a synthesis of geographical investigations of concrete problems in the environment- and nature protection. The contemporary problems of the geographical environment protection caught Slovenian geography in the swirl of hectic and ideologically hued dispute about the unity or duality in geography. The acute problems in nature- and environment protection somehow 'forced' the Slovenian geography, too, that contrary to the dogmatic variety of Marxism, and the related majority of Soviet geography in particular, it spoke even more fervently in favour of the unity of geography. Pollution of geographical environment and its components was treated as a landscape resultant which is the sum-total consequence of intertwined functioning and joint effects of physical-geographical and socio-geographical features, while separate study is not an adequate complex geographical response.

The subsequent development of Slovenian environmental geography also exposed the need for a more detailed, partly specialized dealing with the causes and, especially, the
\end{abstract}


landscape consequences of continuing pollution of an individual component of geographical environment (air, water, soil, etc.). The finding was substantiated that the Slovenian landscapes and landscape-forming elements, due to their different self-purifying capacities, response in a different way to environmental burdens, which has to be taken into consideration in the planning of regional and spatial development.

The methodological upgrading of geographical investigation into an individual environmental burdening activity (source of burdening the geographical environment) in the 1980 2009 period can be clearly followed, for example, through researches into the environmental dimensions of agriculture and rural areas, from the initial instructions for research conduct to the complex, quantitatively contrived questionnaires and realized research models for agrarian (over)burdening of landscape environment and the modelling of development strategies for Slovenian rural areas and geographical regions by taking account of environmental, sustainable points of departure. Similar is the situation in the environmentally devised researches into the problems of Slovenian towns, in which case the regionally-geographically devised investigation into the urban degradation problems continued and intensified, with a greater emphasis on social-geographical problems and, in the latest period, also on sustainable dimensions of urban development.

Investigation into the pollution of individual landscape-forming components of the environment and the causes of their degradation focused mainly on concrete studies of pollution of air (and of noise), water and soil. From the viewpoint of complexly schemed landscapegeographical investigation into an individual landscape-forming element, the methodology and contents of later investigations were modelled on the example of the contribution by D. Radinja (1988b) dealing with the wider degradation problems of Lake Bled in view of its landscape structure. Considering the acute problems of pollution of waters and air in particular, one could expect an even greater geographical research interest for the abovestated problems, which, to a certain extent, also applies to the topical issue of climate changes. Likewise, only a modest attention has been paid to the planetary and European dimensions of environmental pollution and its related social and economic problems which, however, does not apply to the continued varied geographical researches also into the environmental aspects of the development of tourism and recreation.

In contrast to the attention devoted to the complex geographical research potential and tradition, only marginal attention was paid to the polluted or degraded geographical areas of Slovenia, which is partly also due to the above-mentioned more thorough researches into the pollution of Slovenian towns. However, the researches in the field of landscape ecology continued, with the emphasis on the study of landscape-ecological structure and urban ecosystems. In more widely comprehended research field of landscape ecology, an original model developed, of researching environmental vulnerability, which proceeds from the previous landscape-ecological division of the discussed area and, despite certain objective limitations, provides the framework, synthetic and inter-comparative research into the extent and degree of the landscape vulnerability of individual elements and of the environment as a whole.

The classically devised study of nature protection developed in the past few years into the sustainable research of specific features of regional development in the protected areas. In the above-stated research field of environmental geography at the Department, a gradual 
expansion has been more and more evident of the previously narrower scheme of protection contents towards the protection-developmental investigation on the basis of gradually emerging integral geographical sustainable research model and the multi-level (economy, society and environment) comprehension of the indicators of regional development.

A similar trend of gradual expansion of environmental contents is also manifested in the study of geography.

The author believes that in the future, central environmental investigations and education at the Department should be, in addition to urgent basic theoretical-methodological researches (with the emphasis on the upgrading of the integral research into geographical environmental model and the system of synthetic environmental indicators in particular) and functionally devised integration of the findings of geography of natural disasters (with the emphasis on anthropogenic impacts on their extent and intensity), primarily focused on the following central fields of contents designed in a complex and regional-geographical preferential way:

- ecology geography (with human ecology);

- geography of environmental resources and geography of sustainable development (progress).

The efficiency of responses to future scientific-research, educational and other widely applicable challenges significantly depends not only on specialized environmental investigation of certain members of the Department but also on the extent, degree and (in)efficiency of the 'ecologization' of the Department and the entire Slovenian geography. Naturally, Slovenian geography and the Department cannot 'afford' merely a thorough environmental research at the cost of neglecting other, equally important fields of contents, or the alluring illusion that the geographers have, due to the traditional and deep-rooted environmental geographical genes, a comparative advantage over other sciences about space, environment, the relation between a human and environment, nature. Geography, proceeding from a complex landscape analysis, should thus be capable of making a correct environmental diagnosis of geographical areas in Slovenia, and it should also be capable of foreseeing the consequences of welfare in different local conditions or space units (i.e. environment), thus giving regional environmental prognosis.

(Translated by Branka Klemenc) 